\title{
Providing Geomedia Skills beyond (Post)Secondary Education
}

\author{
Robert VOGLER ${ }^{1}$ and Sabine HENNIG ${ }^{1}$ \\ ${ }^{1}$ Z_GIS, Salzburg/Austria ·robert.vogler@sbg.ac.at
}

This contribution was double-blind reviewed as full paper.

\begin{abstract}
In the last years the way how we communicate and exchange information has undergone significant changes. The relevant processes are increasingly Web 2.0-mediated and enable reflective and participatory practices. As part of this development, the use of geomedia in everyday life (both in work life and private life) has gained in importance. The intrusion of new communication channels and media is closely related to discussions and research on topics such as geo-communication, spatially enabled society and spatial citizenship.
\end{abstract}

A competent handling of geomedia requires everyone to develop new and/or more sophisticated capabilities and abilities. While very recently school education has started to impart geomedia competencies, opportunities for (Geo-)ICT empowerment for adults are rather rare. Suitable activities on adult education and learning should be established for various reasons (e.g. social inclusion, information access). This is in line with efforts of the European Union to address the demand to increase and intensify approaches to adult education and learning.

Facing the existing gap between adults' geomedia literacy on one hand and the promises of a spatially-enabled society on the other, this paper discusses the topic of how everyone in society can become spatially literate, i.e. how adults can develop and strengthen their geomedia competencies. This discussion is illustrated with experiences from the pilot course "Geomedia 55+" (held in cooperation with the "University 55+" at Salzburg University, Austria) that aims at teaching geomedia skills for elderly people.

\section{Background and Motivation}

Our society is becoming increasingly interconnected. More than ever effective communication processes are an essential part of everyday life. Due to tremendous advances in Information and Communication Technologies (ICT), information exchange and the way we catch up on content increasingly takes place through Web 2.0-mediated communication which is primarily characterised by user interaction as well as participation and co-operation of a multitude of users (O'REILLY 2007). 
In line with the premise that the public meaning of the Internet shifted from a 'virtual reality' metaphor in the late $90 \mathrm{~s}^{1}$ to a digital mash-up of our daily life ${ }^{2}$ available via mobile devices everywhere and at all times (MEYER 2013), digital communication processes involve geo-spatial information in form of user-generated geomedia to a growing extent (VOGLER, HENNIG, JEKEL \& DONERT 2012). The appearance of tools such as digital globes (e.g. Google Earth, Virtual Earth), web mapping applications (e.g. Google Maps, Bing Maps, ScribbleMaps, ZeaMaps, UMapper), GPS-enabled mobile devices and locationbased services (e.g. Foursquare, Qype) triggered and trigger a surge in interest in geomedia and Geo-ICT (ThielmanN, VAN DER Velden, Fischer \& Vogler 2011). Geoportals (as interfaces with spatial data infrastructures (SDI)) provide access to spatial data and maps for everyone (DE LONGUEVILLE 2010); popular examples are geoportals in context with the European SDI initiative INSPIRE (see e.g. URL 1) or the European Open Government Data initiative (for example in Vienna; see URL 2).

Furthermore, the integration of geo-spatial information through the use of geomedia provides an important contribution to communication. The shift from traditional communication processes (relying not at all or only to a limited extent on the use of geomedia) towards so called social geo-communication ${ }^{3}$ (mainly relying on geomedia) widely recognised. Hence, in the last years, geomedia and geo-communication are gaining in importance for work life and private life as well as for citizenship rights and duties (FELGENHAUER \& QUADE 2012).

Despite the rapid technological development which opens up numerous opportunities for the evolvement of spatially-enabled societies, some challenges remain. In general, data as well as associated tools are accessible and usable by everyone. This is even true for people who are not endowed with competencies in terms of spatial data, GIS or (traditional) cartography. These days, the use of geomedia (production and consumption; including geomedia-related applications) does not require expert knowledge in cartography and digital mapping. So far, so good; but nevertheless, we face a demographic geomedial divide closely related to society's digital divide (BRANDTZÆG, HEIM \& KARAHASANOVIĆ 2011) which refers to the gap between those who can benefit from the use of geomedia and those who cannot. This relates to the lack of required skills. To overcome this division of society, the development of sophisticated geomedia competencies - which are, however, different from geoinformation (GI) and/or GI expert knowledge - is required. The related issues have recently been integrated in a number of national school curricula across Europe (DONERT 2010). Concepts and approaches that aim to enhance pupils' and students' geomedia competencies have been developed. Examples for pedagogical frameworks in-

1 I.e. 'a second world' or 'the cyberspace' or 'virtual reality'.

2 i.e. the Internet as a digital augmentation of our personal, subjective environment; see also the "Internet of Things" vision (TUTERS \& VARNELIS 2006)

3 Geo-communication is characterised by the use and combination of a multitude of multimedia and geomedia by high numbers of participants and various features that enable user interaction (BRODERSEN \& NIELSEN 2006). In addition to producing and integrating geomedia and multimedia, social geo-communication - as an online process -requires the integration of social aspects of communication such as community building and networking. This allows users to interactively participate in communication processes via Web 2.0-based tools using geomedia combined with multimedia (VOGLER et al. 2012). 
clude the "spatial thinking" approach (NATIONAL RESEARCH COUNCIL 2006) or the "Spatial Citizenship" concept (GRYL \& JEKEL 2012).

However, even though certain (post)secondary geomedia education purposes are considered essential for enabling people to make use of the opportunities provided by geomedia, concepts and approaches to enable the general public to handle geomedia are barely exist. This means that people who are not reached by (post)secondary education, are left behind regarding geomedia skills for geo-communication practices. In order to provide those skills, several open questions need to be answered: (i) What type of capabilities and abilities build up adults' geomedia competencies beyond professional GI domains? (ii) What is special (and differs from (post)secondary education) about enabling adults to competently use geomedia? (iii) What can geomedia education for adults look like in practice?

Beyond (post)secondary education, adult training on competent geomedia handling has different aims and asks for different approaches. Based on a) common prerequisites and recommendations elaborated by adult education didactics (see e.g. BMASK 2010), b) necessary geo-communication abilities based on the framework of "social geo-communication" (HENNIG, VOGLER \& JEKEL 2011) and c) the results of a self-reflecting survey with participants of a pilot course "Geomedia 55+", geomedia competencies for adults can be divided into three categories (see Table 1).

Table 1: Selected issues on geomedia (pre)skills (HENNIG \& VOGLER accepted)

\begin{tabular}{|c|c|c|}
\hline \multicolumn{2}{|c|}{ Technical Geomedia skills } & \multirow{2}{*}{$\begin{array}{l}\text { Example } \\
\text { Web mapping tools }\end{array}$} \\
\hline ICT / Web 2.0 & Register/Login & \\
\hline & Use of multimedia elements & $\begin{array}{l}\text { Find images, videos, audio files, open } \\
\text { them, link them etc. } \\
\text { Find URLs and link them }\end{array}$ \\
\hline & $\begin{array}{l}\text { Publish, spread information and multi- } \\
\text { media elements }\end{array}$ & $\begin{array}{l}\text { Publish your content (Google Blog- } \\
\text { ger; post, comment) }\end{array}$ \\
\hline & Work in a cooperative way & $\begin{array}{l}\text { Web } 2.0 \text { communication and collabo- } \\
\text { ration (Blogs, cloud-based storages) }\end{array}$ \\
\hline & Internet safety and copyright issues & $\begin{array}{l}\text { Intellectual property rights, data } \\
\text { privacy }\end{array}$ \\
\hline \multirow[t]{6}{*}{$\begin{array}{l}\text { Geomedia abilities } \\
\text { (web mapping tools) }\end{array}$} & Use digital maps & $\begin{array}{l}\text { Find, open, navigate (zoom, pan) } \\
\text { maps }\end{array}$ \\
\hline & $\begin{array}{l}\text { Create a map and corresponding fea- } \\
\text { tures }\end{array}$ & $\begin{array}{l}\text { Base map, vector data points, lines, } \\
\text { areas/shapes }\end{array}$ \\
\hline & Add further information & $\begin{array}{l}\text { Create, design, edit information } \\
\text { window, balloon }\end{array}$ \\
\hline & Handle data files & Import, export, transfer data \\
\hline & Output and publish maps & Print, save, export, embed maps \\
\hline & (Re-)use data & Find data, assess data, integrate data \\
\hline \multirow[t]{3}{*}{ Geomedia capabilities } & (Internet) cartography & $\begin{array}{l}\text { Decide for adequate symbology, map } \\
\text { picture, base map } \\
\text { Combine multimedia elements and } \\
\text { geomedia }\end{array}$ \\
\hline & Use Web 2.0 tools & Transfer data, post, comment, discuss \\
\hline & Critical reflection on the power of maps & $\begin{array}{l}\text { Interpret maps and set content in } \\
\text { context }\end{array}$ \\
\hline
\end{tabular}


Geomedia use is based on the use of a series of different ICT tools, and being able to handle a number of applications is a prerequisite. Moreover, it encompasses a number of tasks (produce data and maps, exchange and transfer, publish and share data and maps, improve maps with further information, comment on and discuss maps etc.) that rely on the use of particular applications, including web mapping applications, data transformation tools, blogs/forums.

This requires the ability to manage web mapping tools and associated functionalities. Users must be able to find and open maps, explore (e.g. using navigational tools, legend) and interpret maps. In addition to these basic tasks, users should know how to create their own maps and data, i.e. features (point, line, area), how to import and export data (data file formats, converter tools), how to add multimedia information (using, for example, information windows, integrating links and images), how to out-put and re-use data and maps. In addition, people must be also able to handle a wide range of different (Web 2.0) applications. On the part of the users, this requires the ability and capability to know how to use and combine different tools, which refers to the changed way of information and communication in today's societies (closely linked to opportunities offered by social media).

In this context, it has to be highlighted that building and strengthening geomedia skills with adult education is closely related to current discussions about the need for increasing efforts as regards general adult (especially senior) education across the European Union. This is due to several reasons: Since it is widely acknowledged that learning brings equally important benefits for adults' social inclusion and personal fulfilment, adult learning is considered to be a strong link in the lifelong learning chain. Participation in learning initiatives enables people to secure an active and constructive role in their specific communities and in society more generally. Furthermore, the significance of learning for personal development as well as well-being must not be underestimated (EUROPEAN UNION 2012). In sum, adult education is of high social and economic significance and steadily gaining in importance (KNOWLES, Holton \& SWANSON 2011). This is mirrored by current developments to strengthen adult education on a European scale, especially towards ICT-related topics. Examples include the "LLP-Grundtvig-Programme" (URL 3) or the "European Agenda for Adult Learning” (URL 4).

\section{Practical Experience in Fostering Adults' Geomedia Skills}

Adult education and learning frameworks provide numerous recommendations: To be successful, adult learning initiatives need to be of high quality, attractive and within reach of all citizens (EUROPEAN UNION 2012). In order to endow adults (especially seniors) with geomedia competencies, a number of particular constraints and challenges need to be considered. The following insights on how to best meet these challenges were gained in a pilot workshop "Geomedia 55+". The workshop was held in winter term 2012/13 in cooperation with the program "University 55+" by the University in Salzburg, Austria (URL 5). It was also supported by the European network "digital-earth.eu" (URL 6) which focuses on the exchange of experiences and the elaboration of teaching materials for geomedia competencies. 


\subsection{Course Example "Geomedia 55+"}

The pilot course "Geomedia 55+" aimed at providing basic skills and principles of geomedia use for elderly people. It had 19 participants aged $55-84^{4}$. The ex-ante preparation of the course was somehow 'black-boxed' due to a lack of knowledge about the abilities of the target group. Therefore, the purpose of the course was amended and adjusted in consultation with the participants during the course. Table 2 shows the final structure and content.

Table 2: Overview on structure and content of the pilot course "Geomedia 55+"

\begin{tabular}{|c|c|c|c|}
\hline & Lessons/ Units & content & purpose \\
\hline \multirow{6}{*}{ 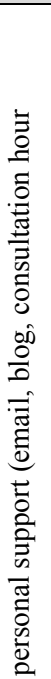 } & $\begin{array}{l}\text { Introduction/ } \\
\text { First practical lessons }\end{array}$ & $\begin{array}{l}\text { Presenting own perspective } \\
\text { Giving theoretical background } \\
\text { Gaining some first own practical } \\
\text { experience }\end{array}$ & $\begin{array}{l}\text { Get an insight at participants state } \\
\text { of abilities }\end{array}$ \\
\hline & Sweetener & GIS day & $\begin{array}{l}\text { Provide an overview on the wide } \\
\text { range of GI }\end{array}$ \\
\hline & $\begin{array}{l}\text { Abilities: data and } \\
\text { maps }\end{array}$ & $\begin{array}{l}\text { Theoretical Background } \\
\text { Practical experience }\end{array}$ & $\begin{array}{l}\text { Introduce basic functions of } \\
\text { geomedia }\end{array}$ \\
\hline & Critical Reflection & $\begin{array}{l}\text { Theoretical Background } \\
\text { Practical experience }\end{array}$ & $\begin{array}{l}\text { Provide a critical view on } \\
\text { geomedia regarding (political) } \\
\text { power }\end{array}$ \\
\hline & Project work & $\begin{array}{l}\text { Do a project working (related to an } \\
\text { everyday situation) based on learn- } \\
\text { ing transfer (prepare a digital map } \\
\text { visualizing a self-chosen topic incl. } \\
\text { data gathering and management; } \\
\text { map layout) }\end{array}$ & $\begin{array}{l}\text { Utilize the basic functions of } \\
\text { geomedia in small conversion } \\
\text { projects }\end{array}$ \\
\hline & Presentation & Present and discuss the projects & Reflect on the work done \\
\hline
\end{tabular}

The purpose of the course was to facilitate geomedia skills in an exemplary way and not to present a variety of different tools and their advantages. Accordingly, the choice of tools was less relevant. For several reasons the course was based on the Google product family which serves as an example for geomedia and modern communication applications based on cloud services. It is free to use and allows for experiencing a number of different activities related to geomedia handling (see HENNIG et al. 2011):

- Google Maps allows users to create and exchange data and maps, even in co-operation. Data can be imported and exported. Multimedia elements can be integrated. Some methods exist to share maps with others (send via email, embed in other applications etc.).

- Google Blogger allows the users to easily publish maps. They can be complemented and enriched by textual information or other multimedia.

- Google+ supports community building and exchange between participants.

4 Age structure: 55-59 years: 5, 60-64 years: 4. 65-69 years: 7, $\geq 70$ years: 3; gender distribution: male: 14 , female: 5 
- Google Drive can be used to share documents among all participants.

Performing the tasks supported by the Google product family the participants learned:

- to use the basic functions of geomedia (in this case: Google Maps and Google Earth; navigation, point of interest (POI) management, polygon management, layer management, data import and export),

- to manage, publish and share produced maps (via Google Drive and Blogger),

- to critically reflect on geomedia and

- to produce and document self-made web-maps (see Figure 1).

With these items the course aimed to enhance participants' geomedia and geo-communication abilities with the help of the Google product family. After learning these basic principles, participants should be able to transfer their knowledge to other tools.

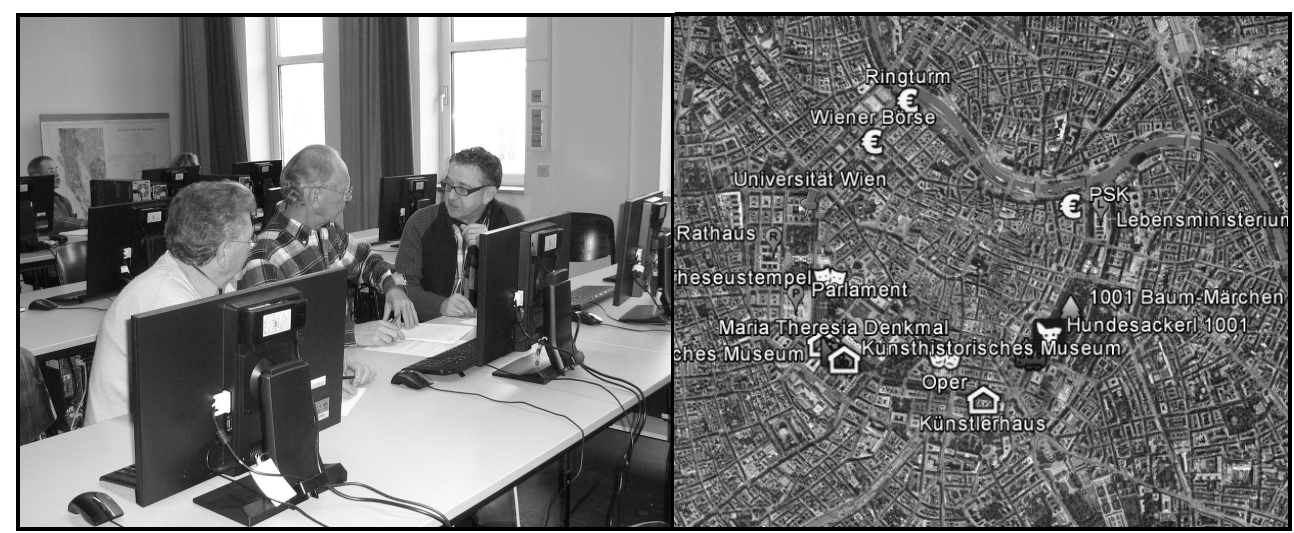

Fig. 1: "Geomedia 55+" in action: course participants during discussion (left) and a produced map showing hotspots in Vienna (right)

\subsection{Constraints}

While empowering adults to competently handle geomedia, we must be aware of three highly important aspects: (1) adults' (especially seniors') ICT background; (2) their motivational set and (3) accessibility barriers of courseware, tools and content.

\section{Participants' ICT background}

Understanding certain ICT (computer handling, internet handling, and web-based communication) constitutes the basis for geomedia use. It encompasses the usage of data, applications and devices. While today's youth is referred to as digital natives, most adults and especially the elderly lack such native understanding of ICT handling (PARLFREY \& GASSER 2008). Necessary skills vary considerable between adults depending on professional background and personal interests. The pilot course "Geomedia 55+" showed that elderly people often have no or only weak ICT background knowledge, unless they were required to be computer-literate in their (former) work life. For instance users face problems with 
- registering for computer programs,

- local data management,

- $\quad$ login to different platforms; personal account management,

- $\quad$ searching, finding and embedding multimedia elements (e.g. images) and

- inserting hyperlinks.

While ICT use is a major prerequisite, the courseware used must address participants' varying ICT background. On the one hand, substantial support and a general modern media introduction must be provided for those who have only little or no ICT knowledge. One the other hand, those who have an advanced background, must be challenged. Therefore, geomedia courses for adults need to be flexibly conceptualised to satisfy the expectations of all participants.

\section{Motivational set of the participants}

While pupils and in part professionals necessarily deal with ICT including geomedia since it is integrated in school education or part of their work, the general public misses such external drivers. Apart from needs triggered by their citizenship rights and duties (see discussions about spatially-enabled society), adults must be considered as self-motivation group. This means that at first sight, no obvious sweeteners exist to encourage them to deal with ICT and geomedia. Getting them involved is a pivotal aspect for raising their awareness of the extent and advantages of a spatially enabled society. Adults must see the benefit of acquiring geomedia competencies. This requires inspiration and drive to motivate them to start activities and to subsequently continue exploring geomedia. As it is the same within general adult education, it is important to link geomedia education with everyday activities (EUROPEAN UNION 2012). Personal experience and knowledge should be integrated and benefits should be drawn from this. Accordingly, the central didactical key principles of geomedia education for adults should be (like in citizenship education in general; see DETJEN 2007): concernment, exemplariness, problem orientation and contemporary relevance.

\section{Accessibility barriers of courseware, tools and contents}

Certain issues (might) hamper and discourage adults from using computers and ICT. Examples are (see e.g. NeusCHMID, HENNIG, SCHRENK, WASSERBURGER \& ZOBL 2012):

- complex computer programmes,

- programmes and applications are often only available in English,

- use of ICT-specific terms,

- $\quad$ poorly documented (work flow) instructions for ICT basics and

- missing additional information (help, user support, glossary etc.).

In all aspects material and tools used in adult ICT learning initiatives must be accessible and usable for this specific user group (EUROPEAN UNION 2012). The exemplary issues stated above should be avoided or at least limited.

\subsection{Methods}

Practical experience and theoretical background concerning adult education and learning in general are also valid for initiatives focusing on empowering adults to handle geomedia. 
Primarily, the support of self-directed learning ${ }^{5}$ plays a pivotal role. Its advantages include the following: it gives individual learners greater freedom of choice, it is flexible and it is by definition specifically tailored to what learners need. In line with key responsibilities relevant for educators, self-directed learning shall focus on "(i) enabling individuals to make informed choices about their development; (ii) providing support on an individual level, in response to specific requests for help, (iii) providing a range of readily available materials and resources from which individuals can choose those best suited to their individual development needs and (iv) coaching, guiding and assisting individuals in using learning resources and materials to their best effect" (URL 7).

Accordingly, applied methods shall focus on encouraging participants to explore existing possibilities and elaborate individual solutions. Units that require personal attendance (faceto face contact) alternate with those relying on self-guided study and self-guided exercises. Lectures (providing necessary background information) shall be combined with exercises (interdisciplinary topics) that build on each other and are closely related to adults' everyday life and experience (BUNDESMINISTERIUM FÜR ARBEIT, SOZIALES UND KONSUMENTENSCHUTZ (BMASK) 2010).

\subsection{Materials and applications}

Useful and valuable materials and tools should fulfil a number of criteria. Due to varying ICT backgrounds and the need to eliminate accessibility barriers only well-documented courseware (material including exercises) and applications should be provided. Regarding the courseware, very detailed explanations (including a glossary) not only allow course participants to repeat exercises in their own time, but also enable self-experience on the part of the users. Proving additional information (access to further information via links) and further exercises supports self-directed learning. The use of applications should be explained in depth. Furthermore, all applications (web-mapping applications; communication tools etc.) should provide help or user support and be available in the course language depending on the target group and background.

These challenges and specific problems encountered in the pilot course "Geomedia 55+" mirror numerous issues also stated in research results related to adult education and training in ICT (see, for example, BMASK 2010).

\section{Conclusion and Outlook}

This paper presented some first practical experiences in adult education and learning in the context of the development of geomedia skills. Due to the missing experiences in the field of geomedia education for adults and especially seniors, the accomplishment of this pilot course can serve as data pool for the prospective development of approaches and materials. It opened up different constraints to be aware of and some crucial demands on methods,

5 Self-directed learning is defined as a process in which learners take the initiative to diagnose their learning needs, formulate learning goals, identify resources for learning, select and implement learning strategies, and evaluate learning outcomes. In self-directed learning environments the role of educators changes from being the "sage on the stage" to the "guide on the side" (URL 8). 
materials and tools. Even if there are a lot of challenges to face (see above), the pilot course itself can be estimated as successful at first sight. Indicators for this assumption are:

- $\quad$ a very low dropout rate ${ }^{6}$,

- unanimously very positive participant feedbacks,

- $\quad$ several participant stated that they (now) consider the topic to be very important and

- an initiative by some of the participants to try to set-up a follow-up workshop in the framework of "University 55+".

But despite these positive items, it became obvious, that still a lot of work must be done to enable adults to competently use geomedia. Learning approaches and materials need to be developed to meet the demands of the target group and corresponding workshop and course offers need to be provided on a large scale (i.e. national and/or European).

In consequence, this paper can and should be interpreted as an awareness-raising statement to include adult education in the future work on providing geomedia skills and competencies. As the EUROPEAN UNION (2012: 5) states: “... the first challenge we need to address is to increase participation in adult learning and to make everyone - learners, providers, stakeholders and policy makers - aware of the benefits of a high quality, easily accessible and equitable adult learning system." This is particularly true if we consider the changing needs of a spatially enabled society: Providing geomedia skills for adults should be a crucial issue across Europe.

\section{References}

ARNOLD, R. \& PÄTZhold, H. (2008), Bausteine zur Erwachsenbildung. Grundlagen der Berufs- und Erwachsenenbildung, Band 53. Baltmannsweiler.

BundESMINISTERIUM FÜR ARBEIT, SOZIALES UND KONSUMENTENSCHUTZ (BMASK) (Ed.) (2010), Internet-SeniorInnenkurse - Leitfaden für TrainerInnen. Wien, Austria.

BrandtzÆg, P. B., Heim, J. \& KarahasanoviĆ, A. (2011), Understanding the new digital divide. A typology of Internet users in Europe. International Journal of HumanComputer Studies, 69 (3), 123-138.

Brodersen, L. \& Nielsen, A. (2006), Spatial Data Infrastructure in the Perspective of Modern Geocommunication. Models, Mutual Dependencies and Definitions. AutoCarto 2006 Research Symposium in Vancouver, WA, Jun 2006.

De Longueville, B. (2010), Community-based geoportals: The next generation? Concepts and methods for the geospatial Web 2.0. Computers, Environment and Urban Systems, 34 (4), 299-308.

DemenY, P. (2011), Demographic Changes and Challenges in Europe. PIE/CIS Discussion Paper (509), Center for Intergenerational Studies, Institute of Economic Research, Hitotsubashi University. http://EconPapers.repec.org/RePEc:hit:piecis:509.

6 Just three out of 19 participants quitted the course (two of them due to the schedule conflicting with other workshops; one because of the low-level/basic character of the course, he expected advanced geomedia handling). This dropout rate is significantly lower than the average of other workshops in the framework of "University 55+". 
DetJen, J. (2007), Politische Bildung. Geschichte und Gegenwart in Deutschland. Munich, Germany.

DONERT, K. (Ed.) (2010), Using Geoinformation in European Geography education, Vol. IX, International Geographic Union, Home of Geography, Rome, Italy.

EUROPEAN UNION (2012), Strategies for improving participation in and awareness of adult learning. European Guide. Publications Office of the European Union, Luxemburg.

Felgenhauer, T. \& QuAde, D. (2012), Society and Geomedia. Some Reflections from a Social Theory Perspective. In: Jekel, T., CAR, A., Strobl, J. \& Griesebner, G. (Eds.), GI_Forum 2012: Geovisualization, Society and Learning. Berlin, Wichmann, 72-82.

GRYL, I. \& JEKEL, T. (2012). Re-centring geoinformation in secondary education: toward a spatial citizenship approach. Cartographica, 41 (1), 2-12.

HENNIG, S. \& VOGLER, R. (accepted), Geomedia skills - a required prerequisite for public participation in urban planning? In: SCHRENK, M., PopOVICH, V. V., ZEILE, P. \& EliseI, P. (Eds.), REAL CORP 2013 Proceedings, pp. pending.

Hennig, S., Vogler, R. \& JeKel, T. (2011), Web-2.0 Anwendungen zur partizipativen Planung und Sozialen Geokommunikation. gis.Science - Die Zeitschrift für Geoinformatik, 3/2011, 65-74.

Knowles, M. S., Holton, E. F. \& Swanson, R. A. (2011), The Adult Learner. The definitive classic in adult education and human resource development. $7^{\text {th }}$ revised edition. Oxford/Burlington.

MEYer, T. (2013), Das Weltweit-Werden und der umgestülpte Cyberspace. In: GRYL, I., NeHRDich, T. \& VogLER, R. (Eds.), geo@web. Medium, Räumlichkeit und geographische Bildung. Wiesbaden, pp. 201-214.

NATIONAL RESEARCH COUNCIL (NRC) (2006), Learning to Think Spatially. GIS as a support system in the K-12 curriculum. National Academies Press, 313 p.

Neuschmid, J., Hennig, S., Schrenk, M., WAsserburger, W. \& Zobl, F. (2012), Barrierefreiheit von online Stadtplänen: Das Beispiel AccessibleMap. In: STROBL, J., Blaschke, T. \& Griesebener, G. (Eds.), Angewandte Geoinformatik 2012. Beiträge zum 24. AGIT-Symposium, Salzburg. Berlin, Wichmann, 339-347.

O'Reilly, T. (2007), What is Web 2.0: Design Patterns and Business Models for the Next Generation of Software. Communications \& Strategies, 1, 17-37.

PARLFREY, J. \& GASSER, U. (2008), Born Digital: Understanding the First Generation of Digital Natives. New York.

Thielmann, T., Van Der Velden, L., Fischer, F. \& Vogler, R. (2011), Dwelling in the Web: Towards a Googlization of Space. In: HIIG Discussion Paper Series No. 2012-03. Berlin, 91 p. http://ssrn.com/abstract=2151949 (January 12, 2013).

TUTERS, M. \& VARNELIS, K. (2006), Beyond locative media. Giving shape to the internet of things. Leonardo, 39 (4), 357-363.

Vogler, R., Ahamer, G. \& JeKel, T. (2010), GEOKOM-PEP. Pupil led research into the effects of geovisualization. In: JeKel, T., Koller, A., Donert, K. \& Vogler, R. (Eds.), Learning with Geoinformation V. Heidelberg, Wichmann, 51-60.

Vogler, R., Hennig, S., JeKel, T. \& Donert, K. (2012), Towards a concept of Spatially Enabled Learning. In: Jekel, T., CAR, A., Strobl, J. \& Griesebner, G. (Eds.), GI_Forum 2012: Geovisualization, Society and Learning. Berlin/Offenbach, Wichmann, $\overline{2} 04-$ 211. 


\section{URLs}

1: http://inspire-geoportal.ec.europa.eu

2: http://data.wien.gv.at

3: http://ec.europa.eu/education/lifelong-learning-programme/grundtvig_en.htm

4: http://ec.europa.eu/education/adult/agenda_en.htm

5: http://www.uni-salzburg.at/portal/page?_pageid $=2487,2057604 \&$ dad $=$ portal\&_schema=PORTAL

6: http://www.digital-earth.eu

7: http://www.dba.co.uk/tips/vol1/self.htm

8: http://www.netnet.org/students/student $\% 20$ glossary.htm 